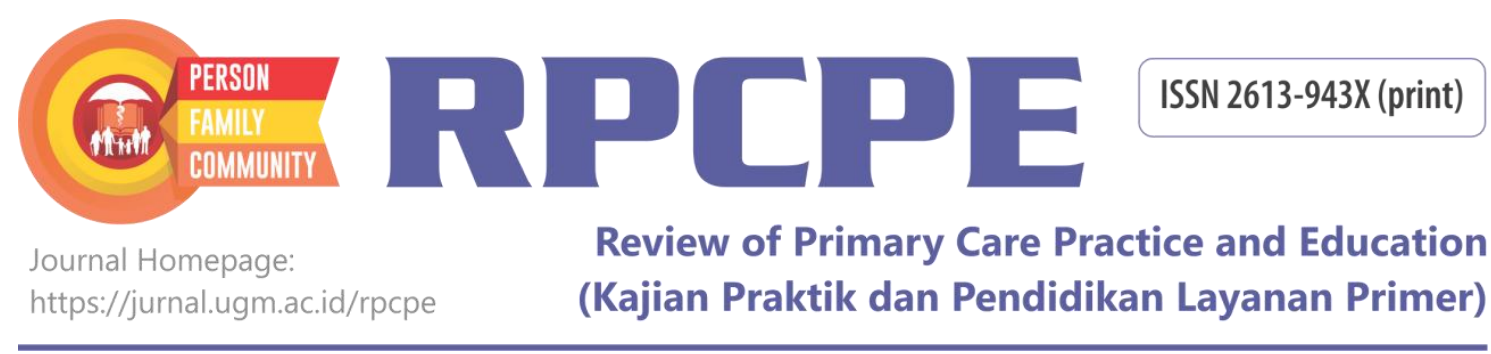

\title{
Impact of Training by Family Doctor on Cadre Performance in Counseling at Posbindu Dusun Tahunan of Gunungkidul Regency
}

T. Herjuna Hadiyanta ${ }^{1}$, Wahyudi Istiono ${ }^{2}$, I Dewa Putu Pramantara ${ }^{3}$

\author{
${ }^{1}$ Puskesmas Paliyan (Community and Primary Health Care Center); Gunungkidul; Yogyakarta; Indonesia \\ ${ }^{2}$ Department of Family and Community Medicine; Faculty of Medicine, Public Health, and Nursing; Universitas Gadjah Mada; Indonesia \\ ${ }^{3}$ Departement of Internal Medicine; Dr. Sardjito Central Public Hospital; Yogyakarta ; Indonesia \\ Corresponding Author: \\ T. Herjuna Hadiyanta: Puskesmas Paliyan, Jl. Raya Paliyan no. 04, Tahunan, Karangduwet, Paliyan, Gunungkidul, Yogyakarta - 55871, Indonesia \\ E-mail: junomichael46a@gmail.com \\ To site this article: \\ Hadiyanta TH, Istiono W, Pramantara IDP. Impact of training by family doctor on cadre performance in counseling at Posbindu Dusun Tahunan of \\ Gunungkidul regency. Rev Prim Care Prac and Educ. 2018; 1(1): 31-36.
}

\begin{abstract}
Background: Increasing cases of non-communicable diseases (NCDs) are becoming a serious public health threat because they dominate the top 10 global causes of death. The government is trying to control it by way of early detection of NCDs risk factors through Posbindu (Integrated Coaching Groups) activities. At this time Posbindu programs are not running optimally because the volunteers called cadres (Kader) are not confident in doing counseling. Cadres find it difficult to read and understand the modules by themselves, while special training on counseling has not been prioritized. Optimally, family doctors as community oriented care providers need to train cadres to be skilled in counseling so that risk factors can be controlled as early as possible. Objectives: The purpose of this study was to assess whether the impact of role playing training by family physicians canimprove the volunteer cadres' performance in providing counseling compared with those who rely on only reading the modules. Methods: The design of this study was a quasi-experimental research with a sample size of 50 participants. The treatmentwas provided in the form of counseling to 11 volunteers (cadres) who were specially trained. Analysis of pre and post-test data used a variety of tests (t-test). Results: Cadres who were trained by family physicians showed a significant increase in mean knowledge level ( $p$ value 0.007) of 22.9. An average increase 4 weeks after training showed no significant difference ( $p$ value 0.346 ) when compared to results immediately after the training. Knowledge of cadres only reading the module showed no significantmean difference $(p$ value 0.6871 ). There was a significant difference of mean knowledge between the trained cadres which was higher than the cadres who only read the modules ( $p$ value 0.005 ). There was also a significant increase in the average knowledge of participants after receiving counseling by trained cadres ( $p$ value 0.001 ) of 22.28. Conclusion: There was a significant increase in cadre knowledge about NCDs risk factors after being specially trained by family physicians. Knowledge of cadres before and after being given modules without training showed no significantchange. There was also a significant increase in participants' knowledge after receiving counseling by trained cadres. Training of cadres with role playing methods was demonstrated to increase participants' knowledge significantly and can be considered a determinant of success in improving cadre performance in counseling.
\end{abstract}

Keywords: education and counseling, non-communicable diseases (NCDs), Posbindu

\section{BACKGROUND}

Non-communicable diseases (NCDs) are a serious problem because its prevalence continues to increase every year. In Indonesia, NCDs are the leading cause of death and the mortality and morbidity rates are increasing ${ }^{1}$. Based on the 10 major causes of death, six are classified as NCDs. The Indonesian government has developed innovations to control NCDs by empowering the community to be able to control NCDs risk factors independently through
Posbindu activities ${ }^{2}$. The implementation of Posbindu still faces various obstacles such as cadres are reluctant to do counseling, since they feel less confident when the government has simply given the learning modules to them when in reality the cadres find it difficult to understand the module. This is understandable because most of the cadres have low education level or are only graduated from elementary or junior high school. Based on this information the researchers who are currently deepening 
education approaches in Family Medical Science and are expected to have a role as the front guards in the primary care service designed an intervention to share in an effort to empower Posbindu cadres to be confident in providing counseling about NCDs by conducting special training to bridge the cadres' limitations in understanding the modules.

\section{RESEARCH METHODS}

This research used quasi-experimental design using one study group and one control group, Convenience ampling was not done with randomization. The level of knowledge was measured by the pre and posttest questionnaires which were previously tested for validation in a place different from the study location. The inclusion criteria in this study were:

a. Participants older than 15 years according to the direction of Ministry of Health.

b. Participants do not experience any hearing loss so as not to experience barriers in receiving information.

c. Participants are willing to be respondents.

Exclusion criterion in this research was any participants who have suffered NCDs.

Univariate analysis was conducted to see the characteristics of respondents consisting of age, sex, education and occupation. The next test looked at the frequency distribution of pretest and post-test results to determine the median value, standard deviation, minimal and maximal, and the mean of pretest and posttest of treatment group, control group and Posbindu participants. Test of distribution of group data of treatment, control and difference between control group and treatment of data distribution used the Shapiro Wilk test. For Posbindu participants the test for data distribution used the Ladder test ( $\geq 50$ subjects). The results of pretest and posttest of each group were analyzed by paired t-test if the data were normally distributed and analyzed with Wilcoxon sign rank test if the data were not normally distributed, with significance level of $p<0.05$. The difference of pretest and post-test results of the treatment group and the control group was analyzed with Mann-Whitney test if the data were not normally distributed. If the data were normally distributed, then the next test variant. If the variant was the same, then the unpaired sample t-test was tested and if the variant was not the same, then unpaired sample t-test unequal was tested, with significance level $p<0.05^{3}$.

\section{RESULTS}

\section{Characteristics of posbindu Dusun Tahunan (treatment group)}

Training of cadres by role playing method was conducted on 11 cadres. Most of the respondents were female, 6170 years old, mean age was 58.81 years, with a standard deviation of 10.03 . The majority of respondents have junior high school education and work as pensioners.

Table 1. Characteristics of posbindu volunteers of Dusun Tahunan

\begin{tabular}{|c|c|c|c|}
\hline No & Characteristics of the subject & Quantity (n=11) & Percentage (\%) \\
\hline & Gender: & & \\
\hline 1 & Male & 4 & 36 \\
\hline \multirow[t]{2}{*}{2} & Female & 7 & 64 \\
\hline & Age: & & \\
\hline 1 & Age $39-50$ years old & 3 & 27 \\
\hline 2 & Age $51-60$ years old & 2 & 18 \\
\hline \multirow[t]{2}{*}{3} & Age $61-70$ years old & 6 & 55 \\
\hline & Latest education: & & \\
\hline 1 & SD (Elementary School) & 1 & 9 \\
\hline 2 & SLTP (Middle School) & 5 & 45 \\
\hline 3 & SLTA (High School) & 4 & 36 \\
\hline \multirow[t]{2}{*}{4} & D3 (College) & 1 & 10 \\
\hline & Job status: & & \\
\hline 1 & Housewife & 3 & 27 \\
\hline 2 & Farmer & 2 & 18 \\
\hline 3 & Retired & 4 & 36 \\
\hline 4 & Entrepreneur & 2 & 18 \\
\hline
\end{tabular}

\section{Characteristics of posbindu Dusun Karang Miri and Grogol (control group).}

The cadre conducted an intervention with modules to 11 respondents. All respondents were female, 41-45 years old, average 41.73 years old with standard deviation 4.78 years. The majority of respondents have high school education and work as farmers.

\section{Characteristics of participants posbindu Dusun Tahunan}

Participants of Posbindu Dusun Tahunan were participants who were counseled by cadres who had been trained to play the role with the number of respondents 50 . Most of the respondents were female, 61-70 age group, mean age 63.02 years with standard deviation 8.99 years. The 
Table 2. Characteristics of posbindu volunteers of Karang Miri and Grogol

\begin{tabular}{|c|c|c|c|}
\hline No & Characteristics of the subject & Quantity $(n=11)$ & Percentage (\%) \\
\hline & Gender: & & \\
\hline 1 & Male & 0 & 0 \\
\hline \multirow[t]{2}{*}{2} & Female & 11 & 100 \\
\hline & Age: & & \\
\hline 1 & Age $30-35$ years old & 2 & 18 \\
\hline 2 & Age $36-40$ years old & 2 & 18 \\
\hline 3 & Age $41-45$ years old & 4 & 36 \\
\hline \multirow[t]{2}{*}{4} & Age $46-60$ old & 3 & 27 \\
\hline & Latest Education: & & \\
\hline 1 & SD (Elementary School) & 2 & 18 \\
\hline 2 & SLTP (Middle School) & 4 & 36 \\
\hline \multirow[t]{2}{*}{3} & SLTA (High School) & 5 & 45 \\
\hline & Job status: & & \\
\hline 1 & Housewife & 4 & 36 \\
\hline 2 & Farmer & 5 & 45 \\
\hline 3 & Laborer & 1 & 9 \\
\hline 4 & Entrepreneur & 1 & 9 \\
\hline
\end{tabular}

Table 3. Characteristics of posbindu participants of Dusun Tahunan

\begin{tabular}{llll}
\hline No & Characteristics of the subject & Quantity $(\mathbf{n}=\mathbf{5 0})$ & Percentage (\%) \\
\hline & Gender: & 6 & 12 \\
1 & Male & 44 & 88 \\
2 & Female & & 6 \\
& Age: & 3 & 38 \\
1 & Age 39-50 years old & 19 & 40 \\
2 & Age 51-60 years old & 20 & 16 \\
3 & Age 61-70 years old & 8 & 12 \\
4 & Age 71-80 years old & & 72 \\
& Latest education: & 6 & 8 \\
1 & Not educated & 36 & 8 \\
2 & SD (Elementary School) & 4 & \\
3 & SLTP (Middle School) & 4 & 42 \\
4 & SLTA (High School) & & 44 \\
& Job status: & 21 & 14 \\
1 & Housewife & 22 & \\
2 & Farmer & 7 &
\end{tabular}

majority are educated up to primary school and work as farmers.

Effect of training by family doctor on knowledge of Dusun Tahunan cadre (treatment group)

The treatment group was the cadre of Posbindu Dusun
Tahunan with 11 people. Before the training the cadres were presented 25 pre-test questions that have been determined to be valid and reliable. Immediately after the training the cadres did posttest stage 1 and 4 weeks after the training cadre again posttest stage 2 .

Table 4. Effects of training on cadres knowledge received by family doctors

\begin{tabular}{lllllll}
\hline No & Test performed & Average value & Standard deviation & Median & Minimal value & Maximum value \\
\hline 1 & Pre-testt & 61.82 & 32.857 & 72 & 16 & 100 \\
2 & Post-test 1 & 84.72 & 17.872 & 92 & 48 & 100 \\
3 & Post-test 2 & 89.82 & 8.830 & 88 & 76 & 100 \\
\hline
\end{tabular}


The test of the distribution of Shapiro Wilk test data showed the results of normal distributed pre-test data $(p$ value 0.063$)$, post-test data of stage 1 was not normally distributed ( $p$ value 0.003 ) and post-distribution data of normalized ( $p$ value 0.890 ) stage 2 posttest.

The result of data analysis paired with pretest and posttest stage 1 using Wilcoxon sign rank test showed significantly increased knowledge of cadres after receiving role playing training ( $p$ value 0.007 ). Increasing the average value of cadre knowledge was 22,9. The result of data analysis paired with pretest and posttest stage 2 using paired t-test showed significantly increased knowledge of cadres after receiving role playing training ( $p$ value 0.011 ). The result of the analysis of paired data between posttest stage 1 and posttest stage 2 was aimed to assess the cadre's knowledge retention 4 weeks after training with Wilcoxon sign rank test, indicating that the increase of cadre knowledge was not significant ( $p$ value 0.346 ). Increasing the average value of cadre knowledge was 5.1.

\section{Knowledge of cadres at Karang Miri and Grogol after reading module (control group)}

The control group with 11 people included Karang Miri Hamlet cadres of 6 people and cadres Grogol of 5 people. Before the module was given, the cadres worked on 25 pre-test questions that were valid and reliable. Immediately after reading the module the cadres did the posttest.

Table 5. Knowledge of posbindu cadres reading modules

\begin{tabular}{lllllll}
\hline No & Test nerformed & $\begin{array}{l}\text { Average } \\
\text { value }\end{array}$ & $\begin{array}{l}\text { Standard } \\
\text { deviation }\end{array}$ & Median & $\begin{array}{l}\text { Minimal } \\
\text { value }\end{array}$ & $\begin{array}{l}\text { Maximum } \\
\text { value }\end{array}$ \\
\hline 1 & Pre-testt & 77.45 & 14.34 & 72 & 56 & 100 \\
2 & Post-test & 76 & 11.03 & 72 & 64 & 96 \\
\hline
\end{tabular}

The Shapiro Wilk data distribution test showed normal distributed pretest ( $p$ value 0.659 ) and post-test data which was also normally distributed ( $p$ value 0.310 ). The result of data analysis paired between pretest and posttest with paired t-test, showed that the average difference of cadre knowledge after reading module was not significant ( $p$ value 0.6871$)$. The average value of knowledge decreased by 1.45 .

\section{Comparative results between treatment group and control group}

The difference of pretest and posttest between the cadre group of treatment and control group, tested the distribution of Shapiro Wilk data with the result that the data distribution of the difference value was normally distributed ( $p$ value $0.0523)$. We then tested variance and got the same variance
( $p$ value 0.134). Because of the same variance, an unpaired $\mathrm{t}$-test was performed. There were significant differences in the knowledge of cadres who received training compared to the cadres who read the module ( $p$ value 0.005 ), where the cadres who received the knowledge level training were higher than those who read the module.

\section{Participant's knowledge after getting counseled by trained cadres}

Participants of Posbindu numbering 50 people from the Dusun Tahunan received counseling about risk factors of NCDs by cadres who have been trained to play the role. Before and after counseling, participants did pretest and posttest with 22 items of questions that have been determined to be valid and reliable.

Table 6. Knowledge of posbindu participants who receive education and counseling by the cadre

\begin{tabular}{lllllll}
\hline No & Test Performed & Average value & Standard deviation & edian & Minimal value & $\begin{array}{l}\text { Maximum } \\
\text { value }\end{array}$ \\
\hline 1 & Pre-testt & 60.20 & 21.84 & 66 & 18 & 91 \\
2 & Post-test & 82.48 & 15.39 & 91 & 36 & 100 \\
\hline
\end{tabular}

The data distribution test using Ladder test shows the data of pretest was not normally distributed ( $p$ value 0.016 ), and posttest was not normally distributed ( $p$ value 0.002 ). The results of paired data analysis between pretest and posttest with Wilcoxon sign rank test showed significantly increased knowledge of participants after getting counseling ( $p$ value $0.001)$. Results showed an increase of the average score of participants' knowledge by 22.28 .

\section{DISCUSSION}

\section{Characteristics of subject research}

Most Posbindu participants are female, elderly age group, and work as farmers. The results of this study indicate that the Posbindu program has not been targeted to all elements of society. Therefore, good communication between cadres and the community is needed to determine the time and place of the proper Posbindu implementation so that more people can attend and if possible it needs to be formed into two or more activities with different times, e.g. (community meeting), social gathering at (female community meeting), at market stalls, in schools, in places of worship, or offices so that people can make visits to Posbindu in the best time and place of interest ${ }^{4}$.

Most Posbindu participants are aged between 61-70 years. Given the large number of elderly visiting the Posbindu program it was very effective as a health counseling program for the elderly by taking into account the risk factors that should be avoided and the protective factors that can be done to improve the health of elderly persons ${ }^{5}$. 
Most of the respondents have low level of education which was elementary so that will have an impact in absorbing information given and hence program providers need to look for counseling methods which are simple and easy understood by respondents ${ }^{6}$. The role of flipchart media is very important as a communication medium between cadres and participants. The flipchart media can bridge the lack of self-confidence of cadres in providing counseling because they are providing health information which are the contents of the flipchart not just the personal opinions of the cadres.

\section{Characteristics of discussion on different (comparison) test results ( $t$-test)}

1. There is a significant increase of knowledge of Posbindu Dusun Tahunan cadres after being trained by the family primary care doctor.

The result of the research shows that there was significant increase of knowledge of the Posbindu cadres after being trained to play the role by the family primary care doctor. Through training with the role play the cadre is trained to demonstrate counseling to fellow cadres which are similar to the real situation. As long as the researchers observed the course of the simulation there was no awkwardness of cadres in doing counseling, and cadres acted full of confidence with the help of back flip media. Between the counselors, the recipient of the message and the audience suggestions were given to each other constructively, with self-assessment, and feedback ${ }^{7}$. According to the results of the training the researchers found the role playing method is very suitable to build the confidence of cadres in Posbindu and this method can be a suggestion to other Posbindu groups to use role play learning methods to overcome cadre obstacles in delivering counseling. Through this method the cadres do not depend on the officers from the local community and the primary health care centers.

2. There is a significant increase of knowledge of the Posbindu participants after getting counseling by trained cadres.

The data of the research shows that the characteristics of the majority of participants in Posbindu who were respondents were educated to the elementary level, were working as a farmer, female, and age group of elderly. The success of counseling in Posbindu Dusun Tahunan cadre in improving the knowledge of participants in addition to being supported by the success of family doctors in providing simulation training was due to the use of props as a means of supporting the flipchart. Through a flipchart, the cadres can easily convey health messages to overcome barriers in communicating. Participants can view the displayed image and the cadre reads the sentence to the participants containing the message or information relating to the image on the flip-chart sheet.

3. There is a significant increase in the level of knowledge of trained Posbindu cadres compared with those reading the module.
According to researchers' observation and supported by Posbindu coach at Paliyan local Community and primary health care, we assume that the reference module given to the cadre is difficult to be studied because of the large amount, the material content and the presentation is hard to be understood by the cadre whose education level is low. According to the researchers the tasks and responsibilities charged by the cadre is very heavy because they have to study the module itself with limited time in addition to their daily tasks of managing the household, earning a living, and other business. Results clearly show that counseling training by family doctors is more important than cadres only reading modules ${ }^{8}$.

\section{Evaluating the impact of cadre performance in counseling}

The performance of cadres can be evaluated from the significantly improved knowledge of Posbindu participants after receiving counseling by trained cadres. The results showed that participants' knowledge increased. This shows that the cadre was doing the counseling in accordance with the duties and responsibilities given to him/her. The performance of Posbindu cadres cannot be separated from the role of coaching and training of related elements that are still considered lacking. During the program the researcher served as a family physician at Paliyan local Community and primary health care center during this new Posbindu training program and he was limited to the technical implementation of Posbindu but was not focused on counseling training on risk factors for NCDs. As a result, the implementation the Posbindu Dusun Tahunan did not run optimally because the cadres did not know what kind of counseling to do when assigned the task. The cadres were only given the module in the form of Smart Book Cadre (Buku Pintar Kader) which they must read and study alone without the help of others. The researcher's experience is also shaped by colleagues who served in other local community and primary health care. They all agreed that the more the cadres participate in the training, the better the performance will be, therefore the training should be done routinely with the distance to the training not too long. The performance of good cadres can then be a determinant of the success of the cadre volunteer building program Posbindu. Kemenkes program policies that are constrained in the field due to the reluctance of cadres to conduct counseling can be overcome by counseling training by family primary care doctors in accordance with the success of our research.

\section{Limitations of research}

The study results have several limitations, namely:

1) Did not use a comparison group on Posbindu participants so that this result cannot illustrate that the increase of knowledge of Posbindu participants is only caused by the provision of education and counseling from Posbindu cadres.

2) In this study we could not control the existence of outside influences such as information from mass media, print and audiovisual as well as other sources 
that can affect the knowledge of respondents.

3) Number of research subjects in the cadre Posbindu treatment group and the small control group were only 11 respondents each, where the results of posttest 1 treatment group, pretest results and posttest control group were not normally distributed, thus cannot accurately describe the complete situation in the entire population.

4) In the Karangmiri and Grogol cadre groups participants who read the module were not exposed to training by family physicians as were the control group. This ethic is not good because the volunteer cadres were only the subjects of research media so they did not directly feel the benefits of training programs from family primary care doctors.

The results showed that there was an increase in cadre knowledge after being trained to play the role (role play) by family doctors rather than only reading the module. Preliminary study results showed that the cadres felt insecure when counseling but were still able to perform well as evidenced by increased participants' knowledge after receiving counseling. The cadres must assume great responsibility if only given the task of reading the module. According to the researcher role-playing method is very suitable to be applied as a government program in order to build cadres' confidence for the successful implementation of Posbindu in the field.

In the implementation in the field, the Cadre Smart Book vol. 1,2,3,4,5 given by Health Ministry is difficult to understand. On the basis of these problems, the researcher assumes that the back flip media can answer the constraints and can bridge the gap so that the information delivered does not come from their own invention but uses the sheet media as the reference. It needs to be made interesting with flipcharts, with images which are easy to learn from, easy to convey the importance of the messages and easily understood by the participants.

As explained above, the performance of Posbindu cadres cannot be separated from the role of coaching from related elements that are still considered lacking. The more the cadres participate in the training the better the performance will be. Training activities should be done on a regular basis with a distance that is not far away. The role play simulation activity is the chosen learning method to improve cadre performance.

\section{CONCLUSIONS}

Training of cadres with role play methods has been demonstrated to significantly increase the knowledge of the participants who get counseling and can become the determinant of success to improve cadre performance. There was significant increasing of knowledge of Posbindu cadres about NCDs risk factors after being trained by family primary care doctors. There was also a significant increase in knowledge of Posbindu participants after directly receiving information and counseling by trained cadres.

\section{Acknowledgement}

The authors would like to thank all those who have provided support in publishing this work and to the academic community who always gave guidance and passion to us to always learn throughout life in improving our knowledge and mastering our clinical skills as doctors in primary care which demands not only to know health problems but be able to practice knowledge and be able to educate the community and be proficient in empowering the community in order to be independent in applying best health practices. We would like to thank the health cadres, community leaders and stakeholders who are always working together in developing government programs and providing feedback in the implementation so that each program can run effectively and optimally for the achievement of a healthy and productive society. Hopefully this scientific publication can be useful for all parties, especially for doctors in primary care in applying the principle of community oriented care.

\section{Ethical Approval and Informed Consent}

The study was approved by The Medical and Health Research Ethical Committee (MHREC) from the Faculty of Medicine, Universitas Gadjah Mada, Yogyakarta with reference number KE/FK/977/EC/2016.

\section{Funding}

Self-funding.

\section{Availability of Data and Material}

Data and material can be accessed via corresponding author.

\section{Conflict of Interest}

None.

\section{REFERENCES}

1. Lanuois P. Non-communicable diseases are increasing. ASM $70^{\text {th }}$ Dies Natalis, Faculty of Medicine, Universitas Gadjah Mada. 2016;1(1).

2. Ministry of health Republic of Indonesia. Efforts to Control Risk Factors of Non Communicable Diseases. 1st ed. Jakarta: Dirjen P2PL Directorate of Non-Communicable Disease Control. 2012.

3. Najmah. Health Statistics of Stata and SPSS Applications. 1st ed. Jakarta: Penerbit Salemba Medika. 2016. 214 leaves.

4. Ministry of health Republic of Indonesia. Technical Guidelines of Non-Communicable Diseases Integrated Counseling Post (Posbindu PTM). Dirjen P2PL NonCommunicable Disease Control. 2012. 1st ed. 39 leaves.

5. Agency for Health Research and Development. Basic Health Research. Ministry of Health Republic of Indonesia. 2013

6. Latif RV. The association of predisposing factors of cadres (knowledge and attitude of cadres to posbindu) with cadre practice in the implementation of posyandu in the work area Puskesmas Wonokerto. Pena Medika Jurnal Kesehatan (Pena Medika: Journal of Health). 2011;3(1).

7. Bennett D, Dodge K. It was like a mirror: a reflection on filmed role play simulation. E-Journal on-line Department of General Education Faculty of Teaching and Learning Mount Royal University. 2014;1(18).

8. Pratiwi N. The Effect of Balanced Nutrition Training on Improving the Knowledge and Skills of Elderly Posyandu Cadres at Grogol Districs Petamburan Jakarta Barat Tahun 2011 [Bachelor Essay]. Depok: Faculty of Public Health University of Indonesia. 2012. 